\title{
The Analysis of the Components of Project-Based Learning on Social Network
}

\author{
A Case Study of Presentation Skill Course
}

\author{
Kuntida Thamwipat \\ Department of Educational Communications and \\ Technology, \\ King Mongkut's University of Technology Thonburi, \\ Bangkok, Thailand
}

\begin{abstract}
This research aims to analyze the components of project based learning on social network, case study of presentation skill course. The study was carried out with 98 representatives of $2^{\text {nd }}-3^{\text {rd }}$ year students of Educational Communications and Technology Department, $2^{\text {nd }}$ semester, academic year 2554, who was studying ETM 205 Presentation Skill. 5 point-rating scale questionnaire was used as the research tool for data collection for analyzing the obtained data which has the reliability as 0.94 and using the mean, Standard Deviation (S.D.), factor analysis, varimax method in data analysis. The results can be concluded as follows: Ten components of project based learning on social network, case study of Presentation Skill course was divided into 3 steps following Ministry of Education's framework as follows: 1) Pre-Project Stage consists of the $3^{\text {rd }}$ component: The introduction of presentation skill and sharing ideas through social network, the $5^{\text {th }}$ component: The learner preparation of pre-project stage, the $9^{\text {th }}$ component: Writing the schemes and skills development training and the $10^{\text {th }}$ component: The presentation skill training in group and individual 2) While / During-Project Stage consists of The $2^{\text {nd }}$ component: Roles and responsibilities during project stage and communication, the $6^{\text {th }}$ component: Readiness of performing duties of individual or group of people which communicate through social network and the $8^{\text {th }}$ component: Guidance and agreement which learner submit voluntarily 3) Post-Project Stage consists of the $1^{\text {st }}$ component: Evaluations, document management system, presentation, the $4^{\text {th }}$ component: Instructor evaluation, feedback, congratulations to learners who achieve successful project and the $7^{\text {th }}$ component: Multi-channel evaluation by regression equation or forecast equation concerning the analysis of the components of project learning management on social network, results as below:
\end{abstract}
$Y=.780($ Factor 1) $+.603($ Factor 2) $+.686($ Factor 3) + $.591($ Factor 4) $+.741($ Factor 5) $+.912($ Factor 6) + $.632($ Factor 7) $+.824($ Factor 8) $+.689($ Factor 9) + $.686($ Factor 10)

This forecast equation has 60 percent accuracy and deviation as 10.00

Keywords-analysis of the componenst; project-based learning; social network; Presentation Skill course.

\author{
Napassawan Yookong \\ Department of Educational Communications and \\ Technology, \\ King Mongkut's University of Technology Thonburi, \\ Bangkok, Thailand
}

\section{BACKGROUND AND RATIONALE}

Thai society at the moment has changed dramatically and rapidly in terms of economic, political, social and cultural aspects. The consequence from such changes means the development of sciences which grows in a rapid manner. According to numerous studies, computer has played a major role in such changes and it is widely used. Since computer has been upgraded all the time, users can have more choices to meet their demands and requirements. At the present moment, internet is becoming more popular and more people are surfing the internet for communication, information exchange, knowledge and entertainment to keep informed of the current situations.

Social networks are beneficial because they enable people to connect, to make friends, to communicate and to provide services to many groups of people. These websites usually contain bases for people to come and make friends through their tools to facilitate their online community. Users can establish their groups of the same interest and get connected to those who they are familiar with. The tools which they use could be e-mail, web board, and blog. Every user can share their profile, information and interesting facts. Besides contact with their friends, users can contact the friends of their friend as well [1].

Nowadays, internet and World Wide Web provides more social network websites. It could be said that social network can create the relationship between you and your friend through the circle of friends. The examples of this kind of social network websites are hi5, facebook and twitter.

Therefore, the use of social network websites for the instruction in classrooms is adopted as a supplement after class in order to give more opportunities of conversation and debate between instructors and students. Now social network is considered to be one approach in education [2].

Project-Based Learning allows learners to interact with communication and real life experience in terms of contents and language for communication during their project. Learners have opportunities and choices to make and they will respect others' opinions. 
Moreover, they need to motivate themselves to gain authentic interest in the subject matter. With Project-Based Learning, learners encounter systematic working in accordance with plans, work as part of the team, exercise their creativity, build up their confidence, and more importantly, create a new body of knowledge on their own. Still, learners need guidance and supervision and this is the gap in which social network can prove useful because instructors could use social network for communication with students.

Presentation Skill course is a course from Department of Educational Communications and Technology, Faculty of Industrial Education and Technology, King Mongkut's University of Technology Thonburi. In this research case study, it was held in the second semester. Instructor in this course applied Project-Based Learning for instruction along with various activities for students to participate. Therefore, the researchers needed to analyze the components of Project-Based Learning on social network with a case study on Presentation Skill course in order to know the proper components for the design of Project-Based Learning on social network in the future.

\section{RESEARCH OBJECTIVE}

This research on the analysis of the components of ProjectBased Learning on social network with a case study on Presentation Skill course was aimed to analyze the components of Project-Based Learning on social network and the Presentation Skill course was used as a case study.

\section{EXPECTED OUTCOMES}

1. Instructors would know the proper components of Project-Based Learning on social network and could use these results to develop and revise the current instructional conditions of Project-Based Learning on social network.

2. This research would become useful for the development of Project-Based Learning on social network in the future.

\section{RESEARCH SCOPE}

\section{A. Population in This Study}

The population in this study comprised 98 students in their second or third year in the second semester of the academic year 2554 B.E. (2011). They were from the Department of Educational Communications and Technology, King Mongkut's University of Technology Thonburi who registered in ETM 205 Presentation Skill course [3].

\section{B. Tool Used in This Study}

The questionnaire was used in this study. Its aim was to analyze the components of Project-Based Learning on social network with a case study on Presentation Skill course. There were many items for each component of Project-Based Learning on social network. The questionnaire was based on 5point rating scale.

\section{Experts}

There would be 3 experts in educational instruction and presentation with at least a Master's degree or 5 years of experience in educational instruction and presentation.

\section{TOOL USED IN THIS RESEARCH}

The tool used in this research was the questionnaire on items which affect Project-Based Learning on social network.

The developed questionnaire was designed to analyze according to the frequency and it was based on Likert's 5-point rating scale. The data would be analyzed using mean and standard deviation.

The statistical approach to this research was factor analysis with orthogonal factor rotation, i.e. Varimax method.

\section{RESEARCH RESULTS}

Table I shows the confirmatory factor analysis of 10 factors.

TABLE I. CONFIRMATORY FACTOR ANALYSIS OF 10 COMPONENTS

\begin{tabular}{|c|l|c|}
\hline Rank & \multicolumn{1}{|c|}{ Component } & Weight \\
\hline 1 & $\begin{array}{l}\text { Readiness of performing duties of individual or } \\
\text { group of people which communicate through } \\
\text { social network }\end{array}$ & .912 \\
\hline 2 & $\begin{array}{l}\text { Guidance and agreement which learner submit } \\
\text { voluntarily }\end{array}$ & .824 \\
\hline 3 & $\begin{array}{l}\text { Evaluations, document management system, } \\
\text { presentation }\end{array}$ & .780 \\
\hline 4 & The learner preparation of pre-project stage & .741 \\
\hline 5 & $\begin{array}{l}\text { Writing the schemes and skills development } \\
\text { training }\end{array}$ & .689 \\
\hline 6 & $\begin{array}{l}\text { The introduction of presentation skill and } \\
\text { sharing ideas through social network }\end{array}$ & .686 \\
\hline 7 & $\begin{array}{l}\text { The presentation skill training in group and } \\
\text { individual }\end{array}$ & .686 \\
\hline 8 & \begin{tabular}{l} 
Multi-channel evaluation \\
\hline 9
\end{tabular} & $\begin{array}{l}\text { Roles and responsibilities during project stage } \\
\text { and communication }\end{array}$ \\
\hline 10 & $\begin{array}{l}\text { Instructor evaluation, feedback, } \\
\text { congratulations to learners who achieve } \\
\text { successful project }\end{array}$ & .632 \\
\hline
\end{tabular}

a. Standard error of estimate was 10.00 b. Cumulative predictive power was $60.00 \%$

According to the data analysis, it was found that 10 independent variables or components have a correlation with Project-Based Learning on social network with a case study on Presentation Skill course. The value ranged from .591 to .912 and the correlation was high. All 10 components formed cumulative predictive power of $60.00 \%$ and the standard error of estimate was 10.00. The weight of components which affect Project-Based Learning on social network could be rearranged as follows: 1) Readiness of performing duties of individual or group of people which communicate through social network; 2) Guidance and agreement which learner submit voluntarily; 3) Evaluations, document management system, presentation; 4) The learner preparation of pre-project stage; 5) Writing the schemes and skills development training; 6) The introduction of presentation skill and sharing ideas through social network; 7) The presentation skill training in group and individual; 8) Multi-channel evaluation; 9) Roles and responsibilities during project stage and communication; and 10) Instructor evaluation, feedback, congratulations to learners who achieve successful project. 
The researchers adopted the framework from Department of Curriculum and Instruction Development, Ministry of Education [4] to divide Project-Based Learning into 3 steps and rearrange the factors as follows:

A. Pre-Project Stage

This stage contained the following components:

- The $3^{\text {rd }}$ component: The introduction of presentation skill and sharing ideas through social network

- The $5^{\text {th }}$ component: The learner preparation of preproject stage

- The $9^{\text {th }}$ component: Writing the schemes and skills development training

- The $10^{\text {th }}$ component: The presentation skill training in group and individual

B. While / During-Project Stage

This stage consisted of the following components:

- The $2^{\text {nd }}$ component: Roles and responsibilities during project stage and communication

- The $6^{\text {th }}$ component: Readiness of performing duties of individual or group of people which communicate through social network

- The $8^{\text {th }}$ component: Guidance and agreement which learner submit voluntarily

C. Post-Project Stage

This stage consisted of the following components:

- The $1^{\text {st }}$ component: Evaluations, document management system, presentation

- The $4^{\text {th }}$ component: Instructor evaluation, feedback, congratulations to learners who achieve successful project

- The $7^{\text {th }}$ component: Multi-channel evaluation

\section{RESEARCH RESULT SUMMARY}

A. Evaluation of Each Item as Regards the Components of Project-Based Learning on Social Network with a Case Study on Presentation Skill Course

According to the study of 45 items individually which affect Project-Based Learning on social network with a case study on Presentation Skill course, it was found that the mean score was between 3.73 and 4.14 with standard deviation of between .680 and .909 . This means that the all items as regards the components of Project-Based Learning on social network with a case study on Presentation Skill course were at high level and the deviation in each item was quite low.

B. Analysis of the Components of Project-Based Learning on Social Network with a Case Study on Presentation Skill Course

There were 10 components which are important for ProjectBased Learning on social network with a case study on
Presentation Skill course. The factor meaning of each component could be given below.

- The $1^{\text {st }}$ component: Evaluations, document management system, presentation

- The $2^{\text {nd }}$ component: Roles and responsibilities during project stage and communication

- The $3^{\text {rd }}$ component: The introduction of presentation skill and sharing ideas through social network

- The $4^{\text {th }}$ component: Instructor evaluation, feedback, congratulations to learners who achieve successful project

- The $5^{\text {th }}$ component: The learner preparation of preproject stage

- The $6^{\text {th }}$ component: Readiness of performing duties of individual or group of people which communicate through social network

- The $7^{\text {th }}$ component: Multi-channel evaluation

- The $8^{\text {th }}$ component: Guidance and agreement which learner submit voluntarily

- The $9^{\text {th }}$ component: Writing the schemes and skills development training

- The $10^{\text {th }}$ component: The presentation skill training in group and individual

C. Correlation Coefficients of the Components of Project-

Based Learning on Social Network with a Case Study on

Presentation Skill Course

The correlation coefficients between 10 components and 45 items which affect Project-Based Learning on social network with a case study on Presentation Skill course ranged from .424 and .935. The correlation coefficients among 10 components which affect Project-Based Learning on social network with a case study on Presentation Skill course ranged from .591 and 912. The correlation was high whereas the correlation coefficients for internal factors ranged from .002 and .070, with low correlation. The highest item which affects Project-Based Learning on social network with a case study on Presentation Skill course was shared communication channel through facebook. The lowest items were evaluation of skill development as well as presentation during project and selfevaluation by learners to reflect feelings and ideas through facebook.

\section{Independent Variables or Predictors Which Are Selected into Regression Equation or Forecast Equation}

There were 10 independent variables or predictors which are selected into regression equation or forecast equation. When the forecast equation is made for the analysis of components of Project-Based Learning on social network with a case study on Presentation Skill course, it is as follows:

$\mathrm{Y}=.780($ Factor 1$)+.603($ Factor 2$)+.686($ Factor 3$)+$ $.591($ Factor 4$)+.741($ Factor 5$)+.912($ Factor 6$)+$ $.632($ Factor 7$)+.824($ Factor 8$)+.689($ Factor 9$)+$ .686 (Factor 10) 
when

$\mathrm{Y} \quad=\begin{aligned} & \text { Project-Based Learning on social network with } \\ & \text { a case study on Presentation Skill course }\end{aligned}$

Factor $1=$ Evaluations, document management system, presentation

Factor $2=$ Roles and responsibilities during project stage and communication

Factor $3=$ The introduction of presentation skill and sharing ideas through social network

Factor $4=$ Instructor evaluation, feedback, congratulations to learners who achieve successful project

Factor $5=$ The learner preparation of pre-project stage

Factor $6=$ Readiness of performing duties of individual or group of people which communicate through social network

Factor $7=$ Multi-channel evaluation

Factor $8=$ Guidance and agreement which learner submit voluntarily

Factor $9=$ Writing the schemes and skills development training

Factor $10=$ The presentation skill training in group and individual

In summary, it was found that these 10 independent variables or predictors were correlated with Project-Based Learning on social network with a case study on Presentation Skill course. The coefficients ranged between .591 and .912 with high correlation. All 10 coefficients formed cumulative predictive power of $60.00 \%$ and standard error of estimate of 10.00 .

\section{RESEARCH DISCUSSIONS}

\section{A. Pre-Project Stage}

The research results showed that the components of Project-Based Learning on social network with a case study on Presentation Skill course for the Pre-Project Stage consisted of the 3rd component: The introduction of presentation skill and sharing ideas through social network, the 5th component: The learner preparation of pre-project stage, the 9th component: Writing the schemes and skills development training and the 10th component:

The presentation skill training in group and individual; The results from this study are in compliance with Department of Curriculum and Instruction Development, Ministry of Education [4] in that Pre-Project Stage must equip learners with skills so that learners can develop and improve their skills. The results are also in accordance with the research by Brien [5] who found that planning and skill training can help learners achieve their learning objectives according to their desired direction, especially for those who are new to Project-Based Learning or those with low learning achievement. However, it was found that in the Pre-Project Stage learners must be given advice and guidance from instructors so that they can share ideas, brainstorm and present their ideas on social network.
That means learners need to develop their skill and this requires training.

\section{B. While / During-Project Stage}

The research results showed that the components of Project-Based Learning on social network with a case study on Presentation Skill course for the While / During-Project Stage consisted of the 2nd component: Roles and responsibilities during project stage and communication, the 6th component: Readiness of performing duties of individual or group of people which communicate through social network, and the 8th component: Guidance and agreement which learner submit voluntarily. These research results are in accordance with Department of Curriculum and Instruction Development, Ministry of Education [4] in that in While / During-Project Stage learners would apply their skills and language in the activities in a step-by-step manner. Learners will become active in doing their own things and instructors will become facilitators instead.

\section{Post-Project Stage}

The research results showed that the components of Project-Based Learning on social network with a case study on Presentation Skill course for the Post-Project Stage consisted of the 1st component: Evaluations, document management system, presentation, the 4th component: Instructor evaluation, feedback, congratulations to learners who achieve successful project, and the 7th component: Multi-channel evaluation. These research results are in accordance with Department of Curriculum and Instruction Development, Ministry of Education [4] in that in Post-Project Stage learners will assess themselves, their peers and their instructors. There will be congratulations to those who succeed in their projects and the documents will be written up and stored in a systematic manner.

\section{SUGGESTIONS}

\section{A. Suggestions from the Research Results}

According to the research results, the $1^{\text {st }}$ component of Project-Based Learning on social network is Evaluations, document management system, presentation. Therefore, instructors should have more ways to assess students such as self-assessment form, peer assessment form for classroom interaction. Instructors could assess the students during or after the project activities. Moreover, project participants could also have their form to assess the project organizers.

It was found that the $2^{\text {nd }}$ component of Project-Based Learning on social network is Roles and responsibilities during project stage and communication. Therefore, instructors and learners should have their clear roles and responsibilities during the project management so that the can have a clear communication and to understand each other about their responsibilities. Researchers suggest using social network websites (such as facebook) to communicate to everybody and post comments.

The research results showed that the $3^{\text {rd }}$ component of Project-Based Learning on social network is The introduction of presentation skill and sharing ideas through social network. Therefore, instructors should guide their students on how to 
give presentation on social network. There can be samples of demonstration. Afterwards, the instructors and the learners could share their ideas about the skills which the instructors taught. This could be done through social network.

\section{B. Suggestions for Further Research}

1. There can be research on the development of ProjectBased Learning on social network with a case study on Verbal Language for Communication.

2. There can be a comparative study between Project-Based Learning on social network and Project-Based Learning in classroom.

3. There can be an analytical study of components of Project-Based Learning on social network which are applicable in Presentation Skill course.

\section{REFERENCES}

[1] Quick PC Extreme, "Social networking: How it reforms education", [Online], Available: http://www.quickpcextreme.com/blog/?p=4985, 2010, [Retrieved 20 January, 2011].

[2] MGT News, Faculty of Management Sciences, Songkhla Rajabhat University, "Online social network and its advantage for collaborative learning", [Online], Available: http://thanapat.blogspot.com/2009/07/social-network.html, [Retrieved 25 February, 2011].

[3] Registration and Evaluation Division, King Mongkut's University of Technology Thonburi, "Information about Curriculum and Description fo ETM 205 Presentation Skill course", [Online], Available: http://regis.kmutt.ac.th/main.php,[Retrieved 17 December, 2011]

[4] Department of Curriculum and Instruction Development, Ministry of Education, Ways to Assess and Measure Learning Achievement according to Basic Education Curriculum 2544 B.E. Bangkok: Ministry of Education, 2011.

[5] D. P. Brien, "The Teaching and Learning Processes Involved in Primary School Children's Research Projects.", Doctoral dissertation, University of New South Wales, 1995.

\section{APPENDIX}

Screenshots of social network website (facebook) which were used for Project-Based Learning in the academic year 2553 B.E. (2010)

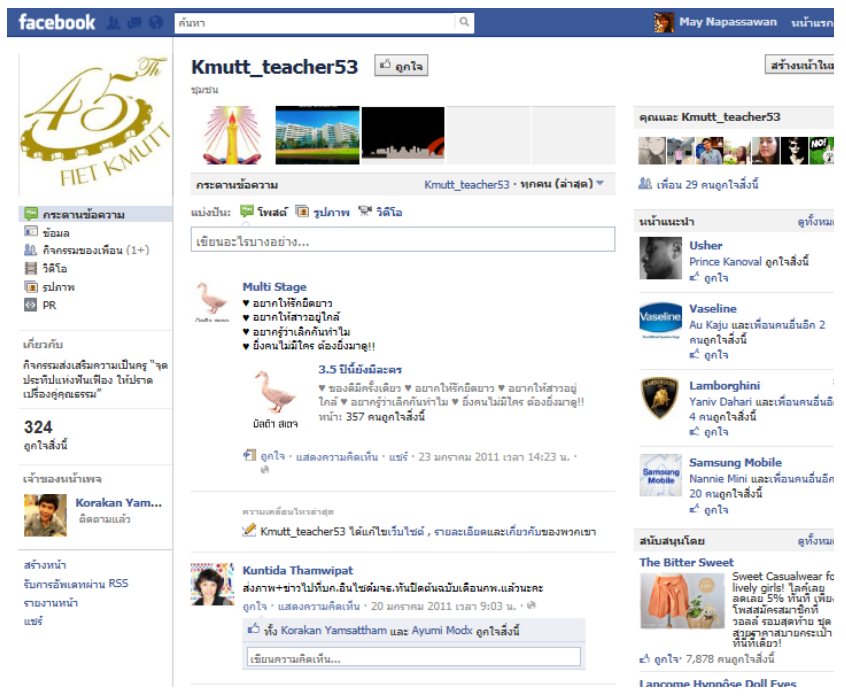

Figure 1. Screenshot of main page for Project-Based Learning (2010)

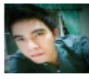

Apiwut Monthakarnkul รักในหลวง

เข้าร่วมๆ จร้าา

ถกใจ * แสดงความคิดเห็น * 11 มกราคม 2011 เวลา 9:12 น. * ผ

匹ู่ ถูกใจ Korakan Yamsattham

เขียนความคิดเห็น

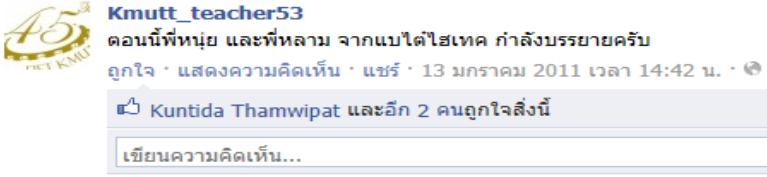

Kuntida Thamwipat

(ไ) สงภาพข่าวงานวันครู'53 ที่ปรับแก๊ไปให้เว็บมาสเตอร์แล้วนะคะ

ถูกใจ · แสดงความคิดเห็น · 14 มกราคม 2011 เวลา 16:08 น. * *

๔ Korakan Yamsattham และอีก 2 คนถูกใจสิ่งนี้

เขียนความคิดเห็น

Figure 2. Screenshot of comments between learners and instructors

Screenshots of social network website (facebook) which were used for Project-Based Learning in the academic year 2554 B.E. (2011)

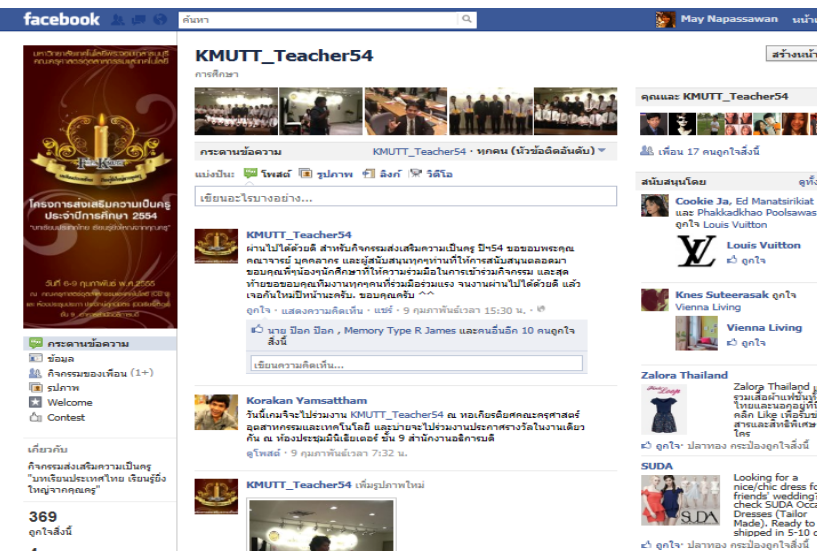

Figure 3. Screenshot of main page for Project-Based Learning (2011)

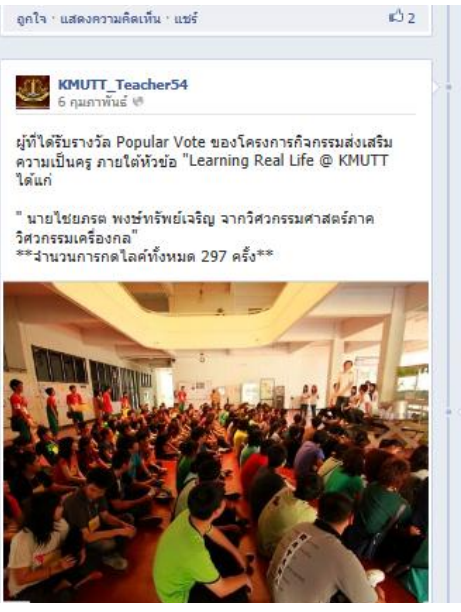

ประกาศ ผู้ที่ใดรับรางวัลประกวดภาพถ่ายของโครงการ สงเสริมความเป็นคร ภายใต้หัวข้อ "Learning Real Life

- รางวัลชนะเลิศอันดับ 1 ได่แก นายพนัญพัฒน์ คุนริ่ คณะวิศวกรรมศาสตร์ กาควิชาวิศว

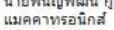

- รางวัลรองธนะเลิศอันดับ 1 ได้แก่ นายพิเชร ไพรอดม คณะวิศวกรรมศาสตร์ กาควิชาวิศวเ

รางวัลรองชนะเลิศอันดับ 2 ได้แก

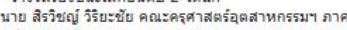

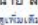

จกใจ - แสคงครานคิลเห็น - แชร์

19. кMUTा_Teacher54

เหลือเวลาอีก 10 นาทีเท่านั้นนะคะ จะปีตผลโหวดแล้ว

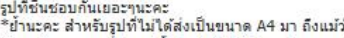
รับการโหวตมากที่สด รูปนี้นลีอว่าไม่ไดรับรางวัล เพราะ

ลกใจ - แสดงความคิดเห็น - แช่

Figure 4. Screenshot of comments between learners and instructors 
AUTHORS PROFILE

Associate Professor Dr. Kuntida Thamwipat is Associate Dean in Information and Student Affair, Faculty of Indutrial Education and Technology, King Mongkut's University of Technology Thonburi
Napassawan Yookong is a graduate student of Department of Educational Communications and Technology, Faculty of Indutrial Education and Technology, King Mongkut's University of Technology Thonburi, Thailand 